\title{
ANALISIS PRAKTIK JUAL BELI PRODUK PERTANIAN BAYAR PANEN DALAM PERSPEKTIF HUKUM EKONOMI ISLAM DI DESA BARUREJO KECAMATAN SILIRAGUNG KABUPATEN BANYUWANGI
}

\section{Lely Ana Ferawati Ekaningsih, Aula Izatul Aini, Imroatul Mutiah Institut Agama Islam Darussalam Blokagung Banyuwangi}

Email: lafwens@gmail.com. aulaizatulaini28@gmail.com.muty.bwi@gmail.com

\begin{abstract}
This study aims to determine the practice of implementing the sale and purchase of agricultural products to pay harvest/respite in Barurejo Village, Siliragung District, Banyuwangi Regency. To find out about the legal views of Islamic economics on the implementation of buying and selling pay harvest. The type of research used in this study is a case study that is single-case design. Data analysis using interactive model analysis techniques. The results of the study, namely the practice of buying and selling are in accordance with the terms and also the pillars of sale and purchase, and buying and selling of this harvest does not contain elements of persecution, because both parties benefit from each other. In the practice of buying and selling agricultural products, the harvest in Barurejo Village, Siliragung Subdistrict, Banyuwangi Regency is in accordance with the objectives of Islamic economic law, namely a sense of empathy among people to create mutual benefit where the price increase the seller gets the price in lieu of the length of payment and the buyer gets the desired item without issuing money in cash, adding a relatively small amount of price and not burdening one party.
\end{abstract}

Keywords: Buying and Selling Practices, Islamic Economic Law.

\begin{abstract}
Abstrak
Penelitian ini bertujuan untuk mengetahui praktik pelaksanaan jual beli produk pertanian bayar panen/tangguh di Desa Barurejo Kecamatan Siliragung Kabupaten Banyuwangi. Untuk mengetahui mengenai pandangan hukum ekonomi Islam terhadap pelaksaan jual beli bayar panen. Jenis penelitian yang digunakan dalam penelitian ini adalah studi kasus yang sigle-case design (desain kasus tunggal). Analisis data dengan menggunakan teknik analisis interaktif model. Hasil penelitian yakni Praktik jual beli sudah sesuai dengan syarat dan juga rukun jual beli, serta jual beli bayar panen ini tidak mengandung unsur penganiyaan, karena kedua belah pihak saling diuntungkan. Dalam praktik jual beli produk pertanian bayar panen di Desa Barurejo Kecamatan Siliragung Kabupaten Banyuwangi sudah sesuai dengan tujuan hukum ekonomi Islam yaitu rasa empati antar sesama menciptakan kemaslahatan bersama dimana penambahan harga tersebut penjual mendapatkan harga sebagai pengganti dari lamanya pembayaran dan pihak pembeli mendapat barang yang diinginkan tanpa mengeluarkan uang secara kontan, penambahan harga jumlah relatif sedikit dan tidak memberatkan salah satu pihak.
\end{abstract}

Kata Kunci: Praktik Jual Beli, Hukum Ekonomi Islam. 


\section{A. Pendahuluan}

Potensi lahan pertanian di Kabupaten Banyuwangi berdasarkan data statistik berada dalam peringkat ketiga setelah Kabupaten Malang dan Kabupaten Jember. Tidaklah mengherankan kalau Kabupaten Banyuwangi menjadi salah satu lumbung pangan di Provinsi Jawa Timur. Disamping potensi dibidang pertanian, Kabupaten Banyuwangi merupakan daerah produksi tanaman perkebunan dan kehutanan. Secara umum struktur ekonomi di Kabupaten Banyuwangi terbentuk dan didominasi oleh sektor pertanian. Sektor pertanian terhadap seluruh kegiatan ekonomi di Kabupaten Banyuwangi angkanya mencapai 36,4 persen, sektor pertanian memiliki konstribusi yang cukup besar berkecimpung dalam bidang pertanian yang meliputi pertanian tanaman pangan, holtikultura, pertanian tanaman perkebunan, peternakan dan hasil- hasilnya, kehutanan serta kelautan dan perikanan.

Saat ini pertanian di Kabupaten Banyuwangi mempunyai dua peran sekaligus tantangan yaitu: mendukung pemenuhan pangan bagi penduduk Banyuwangi juga memberikan lapangan kerja bagi rumah tangga tani. Sebagai sektor yang menjadi tumpuan bagi ketahanan pangan dan mata pencaharian sebagian rakyat, maka pembangunan pertanian merupakan generator bagi pembangunan di Kabupaten Banyuwangi. Karenanya, Kabupaten Banyuwangi mempunyai sumber daya alam yang dapat dimanfaatkan untuk peningkatan peran sektor pertanian dalam pembangunan daerah, yang diharapkan dapat meningkatkan taraf hidup pelaku utamanya yaitu petani (RKPD. 2017).

Kabupaten Banyuwangi memiliki 24 Kecamatan, salah satu kecamatan Siliragung, yang berada dibagian selatan paling barat. Sumber ekonomi yang mendukung adalah pertanian, terbukti mayoritas penduduknya berpenghasilan melalui bertani. Pertanian terbesar di Kecamatan Siliragung terdapat di Desa Barurejo.Desa Barurejo merupakan desa yang memiliki lahan cukup luas dibandingkan dengan desa lainnya di Kecamatan Siliragung Kabupaten Banyuwangi.Berdasarkan profil Desa Barurejo 2017, mayoritas masyarakat di Desa Barurejo dalam memenuhi kebutuhan hidup sehari-hari bergantung dari hasil pertanian. Manusia dalam usahanya mempertahankan kelangsungan hidupnya tidak lepas dari banyaknya masalah, baik masalah ekonomi maupun masalah non 
ekonomi. Di dalam masalah ekonomi sering kali muncul karena untuk memenuhi kebutuhan hidup, sehingga manusia akan melakukan berbagai cara, baik dengan cara membayar lunas, maupun dengan melakukan perjanjian hutang piutang atau tidak dengan jaminan

Petani di Desa Barurejo dalam praktek Jual beli sehari-harinya menyebabkan salah satu pihak dirugikan baik itu penjual maupun pembeli. Pada tahun 2016-2017 di Desa Barurejo terjadi praktek transaksi dimana para petani meminjam uang untuk pembelian produk pertanian, baik itu pupuk maupun obatobatan yang diperlukan untuk bercocok tanam. Pembayaran dilakukan ketika petani tersebut memanen hasil pertaniannya, namun uang yang dikembalikan tidak sama atau lebih besar dari uang yang dipinjamnya. Setelah transaksi tersebut dan diketahui oleh pengurus sekaligus tokoh ulama yang berada di Desa Barurejo Kecamatan Siliragung Kabupaten Banyuwangi, maka transaksi tersebut dihentikan karena pemilik modal di beritahu oleh salah satu tokoh ulama bahwa transaksi tersebut tidak sah menurut pandangan hukum Islam. Meminjam uang dengan pengembalian yang lebih besar tanpa menggunakan akad yang sesuai dapat menjerumuskan salah satu baik itu penjual maupun pembeli. Peminjaman uang sudah dihapuskan akan tetapi masih ada keganjalan yang terjadi di Desa Barurejo Kecamatan Siliragung Kabupaten Banyuwangi.

Keganjalan dari transaksi jual beli di Desa Barurejo, Kecamatan Siliragung, Kabupaten Banyuwangi masih tetap ada, meski transaksi pinjaman uang telah dihapuskan. Petani di Desa Barurejo Kecamatan Siliragung Kabupaten Banyuwangi sebagian besar tidak memiliki modal untuk bercocok tanam, sehingga para petani membeli produk pertanian yang diperlukan untuk bercocok tanam di salah satu toko terbesar yang berada di daerah tersebut, pembelian tersebut tidak dilakukan secara tunai melainkan pembayaran dilakukan ketika para petani memanen hasil pertaniannya (dengan tempo waktu). Karena petani mendapatkan penghasilan ketika sudah memanen hasil pertaniannya, namun ada penambahan harga ketika pembayarannya dilakukan ketika panen. Jual beli dengan sistem ini, oleh masyarakat Desa Barurejo Kecamatan Siliragung Kabupaten Banyuwangi dikenal dengan jual beli bayar panen/tangguh. Praktik kasus jual beli produk pertanian bayar panen/tangguh biasanya dilakukan saat 
terjadinya transaksi jual beli produk pupuk urea dan obat-obatan. Misalnya, pupuk urea yang dijual dengan harga Rp 95.000,-/karung (tunai) dan harga Rp 125.000,-/karung (bayar panen/tangguh), Petani memilih pembelian dengan sistem bayar panen/tangguh $\mathrm{Rp}$ 125.000,-/karung, artinya lebih tinggi Rp 35.000,- dari harga tunai. Obat Rondap eceran dijual dengan harga Rp 44.000,/liter (tunai) dan harga Rp 47.000,-/liter (bayar panen/tangguh), Petani memilih pembelian dengan sistem bayar panen/tangguh $\mathrm{Rp} 47.000,-/$ liter, artinya lebih tinggi Rp 3.000,- dari harga tunai. Dalam transaksi tersebut, telah terjadi kesepakatan antara penjual dan petani (pembeli) bahwa pembayarannya akan dilakukan ketika petani memanen hasil panennya (Miskadi. 2018).

Selisih transaksi jual beli bayar tunai dan jual beli bayar panen/tangguh jika ditinjau dari hukum ekonomi Islam masih terjadi perbedaan pendapat ditokoh masyarakat sehingga menimbulkan kecemasan pada petani. Hasil penemuan tentang pelaksanaan jual beli produk pertanian bayar panen/tangguh, menunjukkan terdapat beberapa hal yang menarik untuk dikaji, yaitu tentang praktik jual beli produk pertanian bayar panen/tangguh yang sudah menjadi kebiasaan masyarakat.

Berdasarkan latar belakang, maka rumusan masalah dalam penelitian ini adalah Bagaimana tinjauan hukum ekonomi Islam mengenai jual beli produk pertanian bayar panen/tangguh di Desa Barurejo Kecamatan Siliragung Kabupaten Banyuwangi?

\section{B. Landasan Teori}

1. Jual Beli Bayar Panen/Tangguh

Jual beli berarti pertukaran sesuatu dengan sesuatu. Kata al-bai' (jual) dan al-syird (beli) dipergunakan biasanya dalam pengertian yang sama, tetapi mempunyai makna yang bertolak belakang. Secara istilah, menurut madzhab Hanafiyah yang dikutip oleh Syafe'I (2001:73) jual beli adalah pertukaran harta dengan harta dengan menggunakan cara tertentu. Pertukaran harta dengan harta disini, diartikan dengan harta yang memiliki manfaat serta terdapat kecenderungan manusia untuk menggunakannya. Cara tertentu yang dimaksud adalah shighat atau ungkapan ijab dan qobul. 
Jual beli bayar tunda dalam al-Qur'an muncul secara implisit dengan kata yang umum al-bai', dalam Hadist muncul secara jelas dengan istilah bai' almuajjal, sama dengan yang digunakan oleh ulama' fikih (bai' al-ajal). Kata Bai' al-ajal/mu'ajal terdiri dari dua kata, bai' dan ajal. Bai' merupakan pertukaran harta dengan harta, berupa barang dengan barang, barang dengan uang atau uang dengan uang. Bentuk-bentuk pertukaran tersebut adakalanya dilakukan dengan tunai, namun adakalanya dilakukan dengan tunda. Model tunai dan tunda adakalanya kedua belah pihak tunai, tetapi adakalanya salah satu pihak tunai sedangkan pihak lainnya tunda. Model tunda juga adakalanya kedua belah pihak tunda adakalanya satu pihak saja yang tunda, pihak yang lain tunai.

2. Hukum Ekonomi Islam

Menurut Syauqi Al Faujani yang dikutip oleh Manan (2012:6), Ekonomi Islam adalah semua hal tentang aktifitas ekonomi yang dibungkus oleh aturan dan juga ajaran Islam tentang sistem ekonomi. Sedangkan hukum ekonomi Islam adalah hukum yang mengatur akan segala hal yang berkaitan dengan sistem ekonomi berdasarkan Al-Qur'an, Hadist, dan ijtihad para ulama. Sesuai dengan perkembangan zaman, hukum ekonomi Islam juga bisa disesuaikan dengan zaman saat ini, namun tetap menggunakan landasan Al-Qur'an, Hadist, dan ijtihad para ulama untuk menyepakati sebuah hukum fiqh yang berlaku.

Hukum dan ekonomi dua hal yang tidak boleh dipisahkan, sebab dua hal ini saling melengkapi seperti dua sisi mata uang. Hukum ekonomi merupakan kajian tentang hukum yang berkaitan dengan ekonomi secara interdisipliner dan multidimensional. Menurut Rachmad Soemitro dirujuk oleh Manan (2012:6)., hukum ekonomi adalah keseluruhan norma-norma yang dibuat oleh pemerintah atau penguasa sebagai satu personifikasi dari masyarakat yang mengatur kehidupan ekonomi dimana kepentingan individu dan masyarakat saling berhadapan. Dalam norma-norma ini pemerintah mencoba memasukkan ketentuan-ketentuan yang lebih ditekankan kepada kepentingan masyarakat, bahkan apabila perlu membatasi kepentingan dan hak-hak individu. Dengan demiakian letak hukum ekonomi, sebagian ada dalam hukum perdata dan sebagian lagi ada dalam hukum publik, dimana keseimbangan kepentingan 
individu dan masyarakat dijaga untuk mencapai kemakmuran bersama dalam kehidupan berbangsa dan Negara.

Hukum Ekonomi Islam menganut prinsip bahwa suatu kemitraan atau perkongsian (syirkah) dianggap sah kalau kemitraan tersebut sudah memenuhi rukun dan syarta-syarat yang telah ditetapkan dalam hukum Islam. Hukum Islam ada lima yaitu wajib, haram, sunah, mubah dan makruh. Menurut Manan (2012:114) rukun kemitraan atau perkongsian (syirkah) dalam syariat Islam ada tiga macam yaitu adanya sighat (ijab kabul) apabila sudah terjadi kesepakatan terhadap sutau hal yang diperjanjikan, pihak-pihak yang melakukan kemitraan (orang-orang yang dibenarkan oleh syariat Islam untuk melakukan kemitraan) dan pokok pekerjaan (bidang usaha yang dikerjakan). Disamping itu juga diperlukan syarat-syarat yang harus ada dalam suatu kemitraan yaitu orang yang melakukan kemitraan harus sehat akalnya, dewasa, balig, dengan kehendaknya sendiri dan barang yang dibuat modal dalam perjanjian harus bernilai dan halal.

\section{Metode Penelitian}

1. Jenis Penelitian

Jenis penelitian yang digunakan adalah studi kasus yang sigle-case design (desain kasus tunggal) dengan pendekatan kualitatif. Studi kasus adalah salah satu metode penelitian ilmu-ilmu sosial. Sedangkan yang dikatakan single-case design (design kasus tunggal) adalah manakala kasus tersebut menyatakan bahwa kasus penting dalam menguji suatu teori yang telah disusun dengan baik. Teori tersebut telah menspesifikasikan serangkaian proposi yang jelas serta keadaan dimana proposi-proposi tersebut diyakini kebenarannya (Yin. 2015:1).

2. Subjek dan Objek Penelitian

Subjek dalam penelitian ini adalah yang menjadi informan yaitu petani yang melakukan jual beli produk pertanian bayar panen/tangguh yang berada di desa Barurejo Kecamatan Siliragung Kabupaten Banyuwangi. Informan yang diwawancarai sebanyak sembilan orang, satu sebagai penjual produk pertanian dan delapan dari petani yang melakukan jual beli produk pertanian bayar 
panen/tangguh. Penelitian ini cukup mewawancara dari sembilan informan karena dari sembilan informan memiliki jawaban yang sama dan memiliki pengetahuan sekaligus pelaku praktik jual beli bayar panen/tangguh.

Objek dari penelitian ini adalah Desa Barurejo Kecamatan Siliragung Kabupaten Banyuwangi, lebih tepatnya Dusun Sumberurip. Dari lima dusun yang berada di Desa Barurejo, Dusun Sumberurip memiliki lahan pertanian yang cukup luas, diantaranya lahan milik sendiri dan juga milik perhutani. Dusun Sumberurip berpotensi sangat besar dalam hal pertanian dan disana marak praktik jual beli bayar panen/tangguh, maka dari itu dusun tersebut sangat mendukung dalam penelitian.

3. Jenis dan Sumber Data

Jenis data yang digunakan dalam penelitian ini adalah data kualitatif yang bersifat deskriptif bukan angka. Data dapat berupa gejala-gejala, kejadian dan peristiwa yang kemudian dianalisis dalam bentuk kategori-kategori (Sugiyono. 2015:221). Sumber data adalah tempat data yang diperoleh dengan menggunakan metode tertentu baik berupa manusia, artefak, dan dokumendokumen. Pada penelitian kualitatif kegiatan ini dilakukan secara sadar, terarah dan senantiasa bertujuan memperoleh suatu informasi yang diperlukan (Sugiyono. 2015:223). Sumber data yang digunakan dalam penelitian ini adalah sumber data primer dan sumber data sekunder

4. Teknik Pengumpulan Data

Dilihat dari segi cara atau teknik dan mekanisme pengumpulan data, teknik pengumpulan data dapat dilakukan dengan teknik observasi (pengamatan), interview (wawancara), kuesioner, dokumentasi, dan gabungan keempatnya. Dalam penelitian kualitatif, pengumpulan data dilakukan pada natural setting (kondisi yang alamiah), sumber data primer, dan teknik pengumpulan data lebih banyak pada observasi, wawancara, dan dokumentasi (Abdullah dan Saebani, 2014:204). Teknik pengumpulan data yang digunakan dalam penelitian ini adalah: Observas, Wawancara, Dokumentasi

5. Teknik Analisis Data

Teknik analisis dalam penelitian ini menggunakan teknik analisis interaktif model yang yang ditemukan oleh Miles dan Hubberman (1984). 
Bahwa aktifitas dalam analisis data kualitatif dilakukan secara interaktif dan berlangsung secara terus menerus sampai tuntas, sehingga datanya sudah jenuh (Sugiyono. 2015:246). Menurut Miles dan Huberman (1984) dirujuk oleh Emzir (2016:129-135), aktivitas dalam analisis data terdiri dari tiga jalur kegiatan yang terjadi secara bersamaan yaitu: reduksi data, penyajian data, dan penarikan kesimpulan/verifikasi.

\section{Hasil dan Pembahasan}

Jual beli produk pertanian bayar panen/tangguh yang dilakukan di Desa Barurejo Kecamatan Siliragung Kabupaten Banyuwangi sudah berjalan sekitar sepuluh tahunan. Dimana awal terjadinya jual beli bayar panen/tangguh adalah ketika banyak petani yang berkeluh kesah dengan seorang penjual produk pertanian yang beliaunya juga merupakan seorang petani di Desa Barurejo Kecamatan Siliragung Kabupaten Banyuwangi. Petani tersebut tidak memiliki modal untuk memulai bertani, penjual produk pertanian memiliki rasa perihatin sehingga memutuskan jual beli dengan cara tunai dan jual beli dibayar ketika petani memanen hasil pertaniannya. Hal ini seperti yang dinyatakan Ibu Sulastri (42) bahwa:

"Faktore seng garakno aku nguwei utangan waktu iko akeh petani seng sambat lek tandurane ora panen krono ura mambu mes blas, tak takoni tibane kape tuku ora nduwe duit. Aku nawani nang salah sijine petani lek tak utangi gelem opo ora, tibane gelem. Teko kedadian iku akeh petani seng ora nduwe bondo sambat utang ben iso podo-podo ambi liyane iso podo tani bareng. Dadi awal mulane aku nyediani mes lan obat-obatan krono aku ngroso nelongso soale aku dewe pernah ngalami".

Jual beli bayar panen/tangguh, pastilah berbeda dengan jual beli tunai. Pada dasarnya jual beli bayar panen/tangguh memiliki selisih harga dengan penjualan tunai. Banyaknya selisih dapat ditentukan oleh sulitnya menemukan produk tersebut seperti pembelian pupuk pertanian. Hasil wawancara dengan Ibu Supiyah (37) bahwa:

"Lek selisihe iki ura pati akeh opo maneh obat-obatan paleng pol Rp 5.000,enek seng selisihe cuma Rp 1000,- juga kok. Lek mes rodok akeh soale lek mes iki kadong angel golek ane yo ra enek tenan. Selisihe lek tuku langsung $R p$ 95.000,- per kebone, lek utangan Rp 110.000,- sampek Rp 125.000,- per kebone". 
Hal ini diperbolehkan berdasarkan kisah nabi Muhammad SAW memerintahkan kepada sahabat Abdullah bin Amr bin Al-ash untuk membeli setiap ekor unta dengan harga dua ekor unta secara pembayaran terhutang. Sudah dapat ditebak bahwa beliau tidak akan rela dengan harga yang begitu mahal bila beliau membeli dengan pembayaran tunai.dan berdasarkan hadits:

"Rasulullah SAW membeli sebagian bahan makanan dari seseorang Yahudi dengan pembayaran terhutang, dan beliau menggadaikan perisai beliau kepadanya" (HR. Al-Bukhori: 1990 dan Muslim 1603).

Semua kebutuhan bertani seperti benih, pupuk, dan juga obat-obatan, petani dapat memperolehnya tanpa harus membayar dimuka. Jual beli produk pertanian cukup dengan adanya perjanjian dan kesepakatan diantara petani dan juga penjual produk pertanian, bahwa petani dan juga penjual tidak merasa keberatan dengan adanya jual beli bayar panen tersebut. Selain kesepakatan dan perjanjian penjual juga memberi nota pembelian sebagai bukti bahwa petani telah melakukan jual beli produk pertanian bayar panen/tangguh. Gunanya nota tersebut agar memudahkan kedua belah pihak, dengan adanya nota petani mengetahui jumlah hutang yang perlu dibayarkan ketika petani memanen hasil pertaniaannya. Sedangkan untuk penjual memudahkan penjual dalam menjumlah hutang. Sehingga penjual lebih cepat dalam pengurangan hasil pertaniannya, karena hasil perolehan akan dikurangi dengan jumlah hutang yang dilakukan oleh petani sejak awal tanam hingga petani memanen hasil pertaniaannya.

Analisis praktik jual beli produk pertanian bayar panen jika dilihat dari syarat dan rukun jual beli sebagai berikut :

1. Syarat jual beli

Syarat Jual beli produk pertanian bayar panen yang dipraktekkan sudah sesuai, syarat aqid terpenuhi, Shighat juga terpenuhi dan barang yang diperjual belikan juga terpenuhi. Hal ini sesuai dengan pernyataan ulama Syafi'iyah dikutip oleh Syafe'I (2001:76) mensyaratkan 22 syarat, yang berkaitan dengan aqid, shigat, dan ma'qud alaih. Persyaratan tersebut adalah:

a. Syarat Aqid

1) Dewasa atau sadar

2) Tidak dipaksa atau tanpa hak.

3) Islam 
4) Pembeli bukan musuh

b. Syarat Shighat

1) Berhadap-hadapan

2) Ditujukan pada seluruh badan yang akad

3) Qobul diucapkan oleh orang yang dituju dalam ijab.

4) Harus menyebutkan barang atau harga

5) Ketika mengucapkan shighat harus disertai niat (maksut).

6) Pengucapan ijab dan qobul harus sempurna.

7) Ijab qobul tidak terpisah

8) Antara ijab dan qobul tidak terpisah dengan pernyataan lain

9) Tidak berubah lafazh

10) Bersesuaian antara ijab dan qobul secara sempurna.

11) Tidak dikaitkan dengan sesuatu

12) Tidak dikaitkan dengan waktu

c. Syarat Ma'qud 'Alaih (Barang)
a) Suci
b) Bermanfaat
c) Dapat diserahkan
d) Barang milik sendiri atau menjadi wakil orang lain.
e) Jelas dan diketahui oleh kedua orang yang melakukan akad.

2. Rukun jual beli

Rukun jual beli dalam praktek Jual beli produk pertanian bayar panen di desa Brurejo sudah sesuai yakni adanya penjual dan pembeli, dan ijab qobul. Rukun jual beli menurut ulama Hanafiyah dikutip oleh Syafe'I (2001:74), rukun jual beli adalah ijab dan qobul yang menunjukkan pertukaran barang secara ridha, baik dengan ucapan maupun perbuatan. Secara umum jual beli terdiri dari tiga rukun. Yaitu: 'aqidain (penjual dan pembeli), ma'qud 'alaih (mabi' dan tsaman), dan shighah (ijab dan qobul) (Pelangi. 2013:4):
a. 'Aqidain
b. Ma'qud 'alaih (barang dagangan)
1) mutaqawwim atau mutamawwal,
2) Muntafa'bih 


\section{3) Maqdur 'ala taslim}

4) Li al-'aqid wilayah

c. Shighah (ijab dan qobul)

Syariah Islam memberikan kebebasan dan kemudahan dalam melakukan muamalah terutama dalam perdagangan atau jual beli, bebas dalam arti tidak bertentangan dengan ketentuan yang telah ditetapkan dalam aturan hukum ekonomi Islam dan tidak merugikan salah satu pihak baik itu penjual maupun pembeli, karena dasar dari muamalah itu harus atas dasar suka sama suka dan tidak terpaksa. Mudah dalam arti tidak menyulitkan antara penjual maupun pembeli.Para ulama dan seluruh umat Islam telah sepakat tentang diperbolehkannya jual beli, karena hal ini pada dasarnya sangat dibutuhkan oleh manusia. Dalam kehidupan sehari-hari tidak semua orang memiliki apa yang dibutuhkannya. Apa yang dibutuhkannya terkadang berada dalam kekuasaan orang lain dan tidak mampu untuk menjadikannya menjadi miliknya. Dengan jalan jual beli maka manusia akan saling tolong-menolong untuk memenuhi kebutuhan hidupnya. Dengan demikian, roda kehidupan ekonomi akan berjalan dengan baik karena apa yang yang mereka lakukan saling menguntungkan kedua belah pihak.

Begitu pula dalam pelaksanaan jual beli produk pertanian bayar panen/tangguh di Desa Barurejo Kecamatan Siliragung Kabupaten Banyuwangi, jual beli tersebut sangat membantu petani yang tidak memiliki modal agar tetap bisa bertani dikarenakan adanya jual beli produk pertanian bayar panen/tangguh. Jual beli produk pertanian bayar panen/tangguh tidak melanggar hukum Ekonomi Islam, karena didalamnya tidak ada unsur riba, gharar maupun keterpaksaan. Dalam pelaksanaan jual produk pertanian bayar panen penjual produk pertanian membantu petani/pembeli dalam memenuhi kebutuhan bertani seperti benih, pupuk, dan juga obat-obatan tanpa harus membayar dimuka namun pembayarannya dilakukan ketika petani memanen hasil pertaniannya. Dalam jual beli produk pertanian bayar panen ini, kedua belah pihak sama-sama diuntungkan baik penjual maupun pembeli. Pembeli diuntungkan karena kebutuhannya bisa tercukupi meski tidak memiliki modal, dan keuntungan untuk penjual mendapakat laba 
sekaligus dapat membantu kebutuhan petani. Setiap muslim diperkenankan melakukan aktifitas jual beli, dalam pelaksanaan perdagangan (jual beli) selain ada penjual dan pembeli, juga harus dengan rukun dan syarat jual beli, dan yang paling penting adalah kedua belah pihak tidak merasa dirugikan.

Menurut Ahmad Azhar Basyir secara garis besar prinsip-prinsip hukum Islam yang dijadikan pedoman dalam melaksanakan aktivitas muamalah adalah sebagai berikut:

1) Pada dasarnya segala bentuk muamalah adalah mubah, kecuali yang ditentukan oleh al-Qur'an dan sunah rasul.

2) Muamalah dilakukan atas dasar suka rela, tanpa mengandung unsurunsur paksaan.

3) Muamalah dilakukan atas dasar pertimbangan mendatangkan manfaat dan menghindari madarat dalam hidup masyarakat.

4) Muamalah dilaksanakan dengan memelihara keadilan, menghindarkan dari unsur-unsur penganiayaan, unsur-unsur pengambilan kesempatan dalam kesempitan.

Prinsip pertama, mengandung maksut bahwa hukum Islam memberikan kebebasan pada setiap orang yang melaksanakan akad muamalah dengan ketentuan atau syarat-syarat apa saja sesuai yang diinginkan, asalkan dalam batas-batas tidak bertentangan dengan ketentuan dan nilai agama. Jual beli produk pertanian bayar panen di Desa Barurejo Kecamatan Siliragung Kabupaten banyuwangi diperbolehkan, karena jual beli tersebut barang yang dijadikan obyek jual beli bermanfaat dan dapat dimanfaatkan oleh manusia, bukan jual beli yang dilarang dalam Islam.

Prinsip kedua, memperingatkan agar kebebasan kehendak pihak-pihak yang bersangkutan selalu diperhatikan. Pelanggaran terhadap kebebasan kehendak seperti adanya unsur paksaan ataupun unsur penipuan, berakibat tidak dibenarkannya suatu bentuk akad muamalah. Antara kedua belah pihak yaitu penjual dan pembeli/petani sama-sama rela dalam melaksanakan transaksi jual beli produk pertanian bayar panen tersebut. 
Prinsip ketiga, memperingatkan bahwa suatu bentuk akad muamalah dilakukan atas dasar pertimbangan mendatangkan manfaat dan menghindarkan dari madharat dalam hidup masyarakat, dengan akibat bahwa segala segala bentuk muamalah yang merusak kehidupan masyarakat tidak boleh. Dalam jual beli produk pertanian bayar panen ini kedua belah pihak, yaitu penjual dan pembeli sama sama-sama mendapatkan manfaat, pembeli mendapatkan produk pertanian untuk kelangsungan pertaniaannya meskipun tidak memiliki modal untuk bercocok tanam dan penjual mendapatkan uang/laba hasil dari penjualan produk pertanian meski itu diperolehnya dalam 4 bulan kedepan.

Prinsip keempat, menegaskan bahwa dalam melaksanakan hubungan muamalah harus ditegakkan berdasarkan prinsip-prinsip keadilan, tanpa mengandung unsur gharar (penipuan) dan jelas dalam setiap ukuran dan takaran pada objek. Dalam jual beli produk pertanian bayar panen objek sudah jelas dan ukurannya pun sudah jelas.

Transaksi jual beli merupakan aktifitas yang dibolehkan dalam Islam, baik disebutkan dalam al-Qur'an, al-Hadits, maupun ijma' ulama (Huda. 2011:53). Adapun dasar hukum jual beli adalah: Firman Allah SWT dalam al-Qur'an Surah An-Nisa' ayat 29

Artinya: Hai orang-orang yang beriman, janganlah kamu saling memakan harta sesamamu dengan jalan yang batil, kecuali dengan jalan perniagaan yang Berlaku dengan suka sama-suka di antara kamu. dan janganlah kamu membunuh dirimu. Sesungguhnya Allah adalah Maha Penyayang kepadamu (Q.S. An-Nisaa':29).

Ayat ini melarang mengambil harta orang lain dengan jalan yang batil (tidak benar), kecuali dengan perniagaan yang berlaku atas dasar kerelaan bersama. Larangan memakan harta orang lain dalam ayat ini mengandung pengertian yang luas dan dalam. Mencari data diperbolehkan dengan cara berniaga atau jual beli dengan dasar kerelaan kedua belah pihak tanpa suatu paksaan. Karena jual beli yang dilakukan secara paksa tidak sah walaupun ada bayaran atau penggantinya. Dalam upaya mendapatkan kekayaan tidak boleh ada unsur zalim kepada orang lain, baik individu atau masyarakat. Tindakan memperoleh harta secara batil, misalnya mencuri, riba, berjudi, 
korupsi, menipu, berbuat curang, mengurangi timbangan, suap-menyuap, dan sebagainya. Kemudian, ayat ini diakhiri dengan penjelasan bahwa Allah SWT melarang orang-orang yang beriman memakan harta dengan cara yang batil dan membunuh orang lain, atau bunuh diri. Itu adalah karena kasih sayang Allah SWT kepada hamba-Nya demi kebahagiaan hidup mereka di dunia dan akhirat (Departemen Agama RI Juz 5. 2009:154).

Pelaksanaan praktik jual beli produk pertanian bayar panen yang ada di Desa Barurejo Kecamatan Siliragung Kabupaten Banyuwangi berdasarkan penelitian dan juga teori tidak melanggar aturan hukum jual beli maupun hukum ekonomi Islam, jadi jual beli produk pertanian bayar panen sah untuk dilakukan dan diperbolehkan menurut syara', karena praktik dilapangan tidak merugikan pihak penjual maupun pembeli. Dalam pelaksanaannya juga disepakati oleh kedua belah pihak. Rukun maupun syarat jual beli sudah terlaksana semua tidak ada yang perlu dicurai dalam pelaksanaan jual beli bayar panen tersebut. Terkait dengan selisih harga petani memaklumi hal tersebut dan petani telah menerima perbedaan jual beli bayar tunai dengan jual beli bayar panen.

Penelitian jual beli bayar panen/tangguh sudah memenuhi syarat dan rukun jual beli. Begitu pula dengan jual beli bayar panen/tangguh ini sudah memenuhi syarat dan rukun jual beli, tidak ada pihak yang dirugikan dengan adanya jual beli bayar panen/tangguh. Jual beli bayar panen/tangguh sangat membantu petani Desa Barurejo yang tidak memiliki modal untuk bertani, dengan adanya jual beli bayar panen petani yang tidak memiliki modal bisa bercocok tanam.

\section{E. Kesimpulan}

Berdasarkan pemaparan diatas dapat diambil kesimpulan bahwa praktik jual beli produk pertanian bayar panen/tangguh yang dilakukan oleh petani di Desa Barurejo Kecamatan Siliragung Kabupaten Banyuwangi yaitu petani melakukan jual beli produk pertanian seperti benih, pupuk dan juga obat-obatan akan tetapi pembayarannya dilakukan ketika petani memanen hasil pertaniannya. Ketika petani memanen hasil petaniannya, pendapatan panen dikurangi hutang dari sejak 
awal tanam hingga petani memanen hasil pertaniannya. Praktik jual beli produk pertanian bayar panen/tangguh di Desa Barurejo Kecamatan Siliragung Kabupaten Banyuwangi tersebut sudah sesuai dengan syarat dan rukun jual beli, serta jual beli bayar panen/tangguh ini tidak mengandung unsur penganiyaan, karena kedua belah pihak saling diuntungkan. Jual beli produk pertanian bayar panen/tangguh mendatangkan manfaat yang lebih banyak daripada madharatnya. Selain itu, praktik jual beli produk pertanian bayar panen/tangguh ini sangat membantu dari segi perekonomian bagi petani terutama petani yang tidak memiliki modal untuk memulai usaha pertaniaannya.

Praktik jual beli produk pertanian bayar panen/tangguh di Desa Barurejo Kecamatan Siliragung Kabupaten Banyuwangi sudah sesuai dengan tujuan hukum ekonomi Islam. Rasa empati antar sesama menciptakan kemaslahatan bersama dimana dalam penambahan harga tersebut penjual mendapatkan harga sebagai pengganti dari lamanya pembayaran dan pihak pembeli mendapat barang yang mereka inginkan tanpa mengeluarkan uang secara kontan. Penambahan harga jumlah relatif sedikit dan tidak memberatkan salah satu pihak.

\section{Daftar Pustaka}

Abdullah, Boedi dan Saebani, Beni Ahmad.2 014. Metode Penelitian Ekonomi Islam Muamalah. Bandung: CV Puspita Setia.

Departemen Agama. 2009. Al-Qur'an Karim. Jakarta.

Emzir. 2016. Metode Penelitian Kualitatif Analisis Data. Jakarta. PT Raja Grafindo Persada

Ghazali, Abdul Rahman. 2010. FiqhMuamalah. Jakarta. Kencana.

Huda, Qomarul. 2011. Fiqh Muamalah. Yogyakarta. Teras.

Manan, Abdul. 2012. Hukum Ekonomi Syariah. Jakarta. Kencana Prenada Media Group

Miles, Matthew B. dan Huberman, A. Michael. 2014. Analisis Data Kualitatif (Penerjemah: Tjejep Rohendi Rohini). Jakarta. Universitas Indonesia (UI-Press).

Miskadi. 2018. Wawancara selaku Petani di Desa Barurejo Kecamatan Siliragung Kabupaten Banyuwangi. 28 Maret 2018.

Muhammad. 2016. Manajemen Keuangan Syariah Analisis Fiqhdan Keuangan. Yogyakarta. UPP STIM YKPN.

Pelangi, Tim Laskar. 2013. Metodelogi Fiqh Muamalah. Kediri. Lirboyo Press.

Soemarsono. 2012. Peranan Harga Pokok dalam Penetapan Harga Jual. Jakarta. Rineka Cipta.

Sugiyono. 2015. Metode Penelitian Kuantitatif, Kualitatif dan R\&D. Bandung. Alfabeta. 
Sulastri. 2018. Wawancara selaku Penjual Produk Pertanian di Desa Barurejo Kecamatan Siliragung Kabupaten Banyuwangi. 20 Mei 2018.

Supiyah. 2018. Wawancara selaku Petani di Desa Barurejo Kecamatan Siliragung Kabupaten Banyuwangi. 10 Juni 2018.

Syafe'I, Rachmat. 2001. Fiqh Muamalah. Bandung. CV PuspitaSetia.

Yin, Robert K. 2015. Studi Kasus Desain dan Metode. Jakarta. PT Raja Grafindo Persada. 